\title{
Isolation, culture and evaluation of Chaetoceros muelleri from the Caribbean as food for the native scallops, Argopecten nucleus and Nodipecten nodosus
}

\author{
Luz Adriana Velasco ${ }^{1}$, Silvia Carrera ${ }^{1} \&$ Judith $_{\text {Barros }}{ }^{1}$ \\ Laboratorio de Moluscos y Microalgas, Universidad del Magdalena \\ Taganga, Santa Marta, Colombia \\ Corresponding author: Luz A. Velasco (molmarcol@gmail.com)
}

\begin{abstract}
The potential of the Caribbean strain Chaetoceros muelleri (CHA-C-04) to be produced and used as diet of two commercially important native scallops (Argopecten nucleus and Nodipecten nodosus) was assessed, using the non-indigenous Chaetoceros calcitrans strain, as a control. Growth and biomass of both diatoms were compared under different culture environments (indoor and outdoor) and culture media (F/2, organic fertilizer triple 15 and humus extract). In addition, their bromatological composition and effect on the physiological condition of the scallops fed with both diatoms were compared. The growth and biomass production of $C$. muelleri and $C$. calcitrans were higher under indoor conditions and using the F/2 media. Although the content of proteins, lipids and energy was higher in $C$. muelleri than in $C$. calcitrans, its size, organic content, growth and biomass values were not different. Scallops fed with both diatoms strains shows similar values for all of the physiological variables measured, including rates of absorption, oxygen consumption, ammonia excretion and scope for growth. Results suggest that the local strain $C$. muelleri can be successfully produced and used in the diet of A. nucleus and $N$. nodosus, but do not offer productive advantages.
\end{abstract}

Keywords: Chaetoceros, bivalves, physiology, nutritive value, microalgae culture, aquaculture.

\section{Aislamiento, cultivo y evaluación de Chaetoceros muelleri del Caribe como alimento para los pectínidos nativos, Argopecten nucleus y Nodipecten nodosus}

\begin{abstract}
RESUMEN. Se evalúa el potencial de la cepa del Caribe Chaetoceros muelleri (CHA-C-04) para ser producida y utilizada como dieta de dos pectínidos nativos de importancia comercial (Argopecten nucleus y Nodipecten nodosus) usando la cepa foránea Chaetoceros calcitrans como control. El crecimiento y biomasa de ambas diatomeas se compararon en diferentes ambientes (interior y exterior) y medios de cultivo ( $\mathrm{F} / 2$, fertilizante orgánico triple 15 y extracto de humus). Además, se comparó su composición bromatológica y efecto sobre la condición fisiológica de los pectínidos alimentados con ambas diatomeas. El crecimiento y la producción de biomasa de $C$. muelleri y $C$. calcitrans fueron superiores en ambientes cerrados y usando el medio F/2. Aunque el contenido de proteínas, lípidos y energía fue mayor en $C$. muelleri que en $C$. calcitrans, sus valores de tamaño, contenido orgánico, crecimiento y biomasa no fueron diferentes. Los pectínidos alimentados con ambas cepas presentaron valores similares para todas las variables fisiológicas medidas, incluyendo las tasas de absorción, consumo de oxígeno, excreción de amonio y crecimiento potencial. Los resultados sugieren que la cepa local $C$. muelleri puede ser producida con éxito y utilizada en la dieta de A. nucleus y $N$. nodosus, pero no ofrece ventajas productivas.
\end{abstract}

Palabras clave: Chaetoceros, bivalvos, fisiología, valor nutritivo, cultivo de microalgas, acuicultura.

\section{INTRODUCTION}

Alive planktonic diatoms are essential components in the diets supplied to bivalve mollusks in hatchery conditions (Albentosa et al., 1997; Ponis et al., 2003). Among the most used and nutritive diatoms are Chae- toceros calcitrans (Paulsen) Takano and C. muelleri Lemmermann 1898 (Brown et al., 1997; MartínezFernández et al., 2004; Cerón-Ortiz et al., 2009; Liu et al., 2009; Petersen et al., 2010; Ragg et al., 2010), which have been isolated from the eastern Pacific or the north-eastern Atlantic, respectively. Those strains are

Corresponding editor: Mauricio Laterça 
commonly imported by the hatcheries around the world, which could present some problems such as the risk of species introduction into natural ecosystems (De Pauw et al., 1984; Andersen \& Kawachi, 2005), lower production parameters due to lack of adaptation to local environmental conditions (Andersen \& Kawachi, 2005) and/or lesser nutritional quality for the local bivalves (Brown et al., 1998; Gouda et al., 2006).

Argopecten nucleus and Nodipecten nodosus are two Caribbean commercially important scallop species which have been produced in hatchery using as food the traditional strains C. calcitrans and Isochrysis galbana (Velasco, 2008). Nevertheless, higher values of growth and reproductive conditioning of A. nucleus and $N$. nodosus has been obtained in sea suspended culture instead in hatchery conditions and it has been attributed to the higher nutritional quality of local microalgae and/or a higher diversity of food items (Rupp et al., 2005; Velasco \& Barros, 2007, 2009; Velasco, 2008). Then, the use of local strains as food for the Caribbean scallops could be more suited considering environmental, productive and/or nutritional parameters.

Although there are some studies about isolating, culture and nutritional evaluation of local marine microalgae strains as food for bivalves (Ewart \& Epifanio, 1981; Brown et al., 1998; Knuckey et al., 2002; Gouda et al., 2006). Local marine microalgae strains are not easily available in the Caribbean zone and there are only a few studies about its isolation and/or culture (Bermúdez et al., 2002; Angarita \& Sánchez, 2003; Prieto et al., 2005), but there are no published studies about their nutritional evaluation for bivalves. In order to use local microalgae strains as food in aquaculture it is necessary to isolate them and find ways to produce high biomass using simple and inexpensive techniques.

Culture media and environment of culture are among the principal factors affecting the microalgal growth and the production costs (Coutteau \& Sorgeloos, 1992; Borowitzka, 1999; López-Elías et al., 2005; Banerjee et al., 2011; Lananan et al., 2013). There are a variety of suitable culture media, including enriched seawater media (Walne, 1966; Guillard, 1975; Harrison et al., 1980) or synthetic media (i.e., ASW, Algal-1). Nevertheless, their use is highly expensive in massive microalgae cultures still using commercial grade reagents (López-Elías \& Voltonina, 1993). Alternative media such as agricultural fertilizers extracts of soils or macrophytes and/or treated waste waters have been used with different results (Fabregas et al., 1987; Sánchez-Saavedra \& Voltolina, 1994; Nieves et al., 1996, 2000; Godínez et al., 2000; Valenzuela-Espinoza et al., 2002). On the other hand, in tropical and subtropical countries microalgae may be grown at indoor conditions, under relatively stable conditions, or at outdoor environments, under variable temperature and irradiance conditions, and at a lower cost (Borowitzka, 1999; López-Elías et al., 2003, 2005).

Direct determination of the microalgae value on the reproductive conditioning and/or growth of bivalves require numerous long-term experiments which place important demands on physical facilities, time, labor, and economic resources. The use of physiological measurements is an alternative method for estimating comparative value among diets, with greater simplicity and in less time, as well as providing more information on the factors responsible of the organism's responses (Widdows, 1985a). The scope for growth is very precise and sensible index of stress conditions when the measurements are made carefully (Widdows, 1985a; Grant \& Cranford, 1991) which is positively correlated with the bivalve growth rate (Bayne et al., 1979; Riisgård \& Randløv, 1981) and gonadic ripeness (MacDonald \& Bourne, 1987; Navarro et al., 2000). This index has been used successfully in A. nucleus and $N$. nodosus in order to select the appropriate temperature and diet hatchery conditions (Velasco, 2006, 2007).

This study was performed in order to evaluate the value of a Colombian Caribbean microalgae strain to be used as live food for native commercially important scallops. First, the strain C. muelleri Lemmermann, 1898 (CHA-C-04) was isolated in the Colombian Caribbean. Then, its growth and biomass production were assessed under different culture conditions, using the traditional strain, C. calcitrans, as a control. Finally, we analyze their bromatological composition and compared the physiological responses of the scallops, A. nucleus and $N$. nodosus, fed with both microalgal strains.

\section{MATERIALS AND METHODS}

\section{Microalgae isolation}

The local microalgae strain were obtained from phytoplankton samples, extracted on March 242004 (2-4 pm), by means of 3 sub-superficial haulages with a mesh of $56 \mu \mathrm{m}$ in the Bay of Taganga, Santa Marta, Colombia $\left(11^{\circ} 16^{\prime} 03^{\prime \prime} \mathrm{N}, 74^{\circ} 11^{\prime} 24^{\prime \prime} \mathrm{W}\right)$. In this region water temperatures are between 26 and $31^{\circ} \mathrm{C}$, salinities between 32 and 36 (Velasco \& Barros 2007, 2009; Velasco et al., 2009a). Phytoplankton samples were located in $200 \mathrm{~mL}$ flasks and translated to the Laboratorio de Moluscos y Microalgas of the Universidad de Magdalena, Taganga $\left(11^{\circ} 16^{\prime} 03^{\prime}\right.$ N , $\left.74^{\circ} 11^{\prime} 24^{\prime \prime} \mathrm{W}\right)$. They were diluted with microfiltered water $(1 \mu \mathrm{m})$, sieved using $10 \mu \mathrm{m}$ mesh sizes, enriched 
with the culture media F/2 (Guillard, 1975), maintained indoor in glass flasks $(500 \mathrm{~mL})$ with constant fluorescent illumination $\left(45 \mu \mathrm{mol}\right.$ quanta $\left.\mathrm{m}^{-2} \mathrm{~s}^{-1}\right)$, at $24^{\circ} \mathrm{C}$ and salinity of 35 . The diatom, C. muelleri, was isolated after 45 days of this mixed cultivation using the techniques of serial dilutions and streaking in plates (Guillard, 1973; Hoshaw \& Rosowski, 1973). Scanning electron microscopy (SEM) was used to identify the diatom isolated. Three samples of $C$. muelleri cultures $(10 \mathrm{~mL})$ were concentrated and rinsed with a tamponed sodium phosphate solution ( $\mathrm{pH}=7.3$ ) by centrifugation. Samples were fixed adding aldehyde glutamate $(2.5 \%)$. Fixed cells were rinsed with distilled water, dehydrated in ethanol (30, 50, 70 and 100\%) and mounted on stubs. Mounted samples were dried by critical point drying and sputter coated with gold before viewing using a FEI SEM Quanta 200-r. Diatom species were identified following the keys in Hustedt (1930) and Rines \& Hargraves (1988). The $C$. calcitrans (Paulsen) strain was obtained from the Centro de Investigaciones Biológicas del Noroeste (CIBNOR), México.

\section{Microalgae culture experiments}

A factorial culture experiment $(2 \times 2 \times 3)$ was done with two microalgal strains: a) Caribbean strain, $C$. muelleri, and b) traditional strain, $C$. calcitrans; testing two culture environments: a) indoor at $24 \pm 0.5^{\circ} \mathrm{C}$, and b) outdoor at $28 \pm 2^{\circ} \mathrm{C}$; and three culture media: a) Guillard f media (F/2; Guillard 1975), b) triple 15 (T15; Nutrimon ${ }^{\circledR}$, Monomeros, Colombia), and c) humus extract $\left(\mathrm{H}\right.$; Nutrimon ${ }^{\circledR}$, Monomeros, Colombia). All of those 12 treatments were realized by triplicate using $200 \mathrm{~mL}$ glasses containers, water at 35 of salinity, compressed air injected and constant fluorescent illumination of $45 \mu \mathrm{mol}$ quanta $\mathrm{m}^{-2} \mathrm{~s}^{-1}$ and initial density of $0.6 \times 10^{3}$ cell $\mu \mathrm{L}^{-1}$. The outdoor treatments were exposed to the same conditions, excepting at the daytime, when artificial lighting were replaced by the solar irradiance, with values as high as $160 \mu$ mol quanta $\mathrm{m}^{-2} \mathrm{~s}^{-1}$. Appropriated quantities of $\mathrm{T} 15$ and $\mathrm{H}$ were diluted in distilled water, sterilized (15 PSI per $60 \mathrm{~min}$ ) and microfiltered $(1 \mu \mathrm{m})$, in order to prepare the stock solutions for media culture with the same total nitrogen of the F/2 stock solution (75 mg L L $^{-1}$ Guillard, 1975). The composition of each medium is presented in Table 1.

The same parental exponential phase culture maintained in the experimental conditions for two generations was used as inoculums in each one of the treatments. Cellular density was determined daily from three samples $(1 \mathrm{~mL})$ collected at the same hour $(4 \mathrm{pm})$ from each of the replica after homogenization. Optical analysis was performed using a Neubaeur plate $(0.1$ $\mathrm{mm}$ of deep) under a microscope.
Table 1. Composition of media cultures tested. Guillard f media (F/2; Guillard, 1975), triple15 (T15; Nutrimon ${ }^{\circledR}$, Monomeros) and humus extract $\left(\mathrm{H} ; \quad\right.$ Nutrimon ${ }^{\circledR}$, Monomeros).

\begin{tabular}{|c|c|c|c|c|}
\hline Constituents & Formula & $\mathrm{F} / 2(\%)$ & $\mathrm{H}(\%)$ & $\mathrm{T} 15(\%)$ \\
\hline Sodium nitrate & $\mathrm{NaNO}_{3}$ & 63.69 & 40.10 & \\
\hline Ammonia nitrogen & $\mathrm{NH}_{4}^{+}$ & - & - & 22.90 \\
\hline Nitric nitrogen & $\mathrm{NO}_{3}{ }^{-}$ & - & - & 10.44 \\
\hline Sodium phosphate & $\mathrm{NaH}_{2} \mathrm{PO}_{4}$ & 4.25 & 5.15 & \\
\hline Phosphoric oxide & $\mathrm{P}_{2} \mathrm{O}_{5}$ & - & - & 33.33 \\
\hline Potassium & $\mathrm{K}$ & - & 33.70 & \\
\hline Potassium oxide & $\mathrm{K}_{2} \mathrm{O}$ & & & 33.33 \\
\hline Sodium silicate & $\mathrm{Na}_{2} \mathrm{SiO}_{3}$ & 25.48 & - & - \\
\hline Cupric sulfate & $\mathrm{CuSO}_{4} .5 \mathrm{H}_{2} \mathrm{O}$ & 0.01 & - & - \\
\hline Zinc sulfate & $\mathrm{ZnSO}_{4} .7 \mathrm{H}_{2} \mathrm{O}$ & 0.02 & - & - \\
\hline Cobalt chloride & CoCla. $6 \mathrm{H}_{2} \mathrm{O}$ & 0.01 & - & - \\
\hline Manganese chloride & $\mathrm{MnCl}_{2} \cdot 4 \mathrm{H}_{2} \mathrm{O}$ & 0.149 & - & - \\
\hline Sodium molybdate & $\mathrm{Na}_{2} \mathrm{MoO}_{4} \cdot 2 \mathrm{H}_{2} \mathrm{O}$ & 0.01 & - & - \\
\hline Ferric chloride & $\mathrm{FeCl}_{3} \cdot 6 \mathrm{H}_{2} \mathrm{O}$ & 2.65 & - & - \\
\hline Disodium EDTA & $\mathrm{Na}_{2}$ EDTA & 3.70 & - & - \\
\hline Biotin & $\mathrm{C}_{10} \mathrm{H}_{16} \mathrm{~N}_{2} \mathrm{O}_{3} \mathrm{~S}$ & 0.001 & - & - \\
\hline Cyanocobalamin & $\mathrm{C}_{63} \mathrm{H}_{58} \mathrm{CoN}_{14} \mathrm{P}$ & 0.01 & - & \\
\hline Thiamine & $\mathrm{C}_{12} \mathrm{H}_{17} \mathrm{CIN}_{4} \mathrm{OS}$ & 0.02 & - & - \\
\hline Magnesium & $\mathrm{Mg}$ & - & 20.45 & - \\
\hline \multirow[t]{2}{*}{ Boron } & B & - & 0.6 & - \\
\hline & Relation N:P & $15: 1$ & $8: 1$ & $1: 1$ \\
\hline
\end{tabular}

$$
\mathrm{D}\left(\text { cel } \mathrm{mL}^{-1}\right)=\mathrm{FD} \times \mathrm{C} \times 10,000 \mathrm{~mL}^{-1}
$$

where D: cell density, DF: dilution factor and C: media number of cells in each quadrant.

Culture volume lost in each replica by effect of sampling and evaporation was replaced daily with distilled and sterilized water. Specific growth rate (K) was calculated using the equation proposed by Fogg (1965):

$$
\mathrm{K}=(\mathrm{LnNf}-\mathrm{LnNi}) / \mathrm{t}
$$

where $\mathrm{N}$ is the initial (i) and final (f) cellular density and $t$ is the duration of the culture until the stationary phase.

Dry biomass of each replica was determined from a daily culture sample $(10 \mathrm{~mL})$ filtered on a glass fiber filter $(1.5 \mu \mathrm{m})$ and dried at $70^{\circ} \mathrm{C}$ for $24 \mathrm{~h}$, following the gravimetric method described by Strickland \& Parsons (1972).

\section{Microalgae characterization}

Bromatological composition of both diatoms were determined from triplicate cultures $(3 \mathrm{~L})$, using $\mathrm{F} / 2$ medium, under the same indoor conditions described above, and using an initial density of $0.2 \times 10^{3}$ cell $\mu \mathrm{L}^{-1}$. Three samples of each microalgae culture $(500 \mathrm{~mL})$ in exponential phase (4 days) were analyzed in terms of cell diameter by microscopy, total particulate matter (TPM) and organic content (POM) following the gravimetric method described by Strickland \& Parsons (1972). Each subsample was filtered on glass-fiber filters (diameter $=$ $0.45 \mu \mathrm{m}$; Millipore) which had been previously washed 
with distilled water, ashed at $450^{\circ} \mathrm{C}$ for $4 \mathrm{~h}$, and weighed. The filtrate was washed with $3 \%$ ammonium formate, dried at $70^{\circ} \mathrm{C}$ for $48 \mathrm{~h}$, and weighed; and finally the filters were ashed at $450^{\circ} \mathrm{C}$ for $4 \mathrm{~h}$ and re-weighed. Protein quantification was carried out according to Lowry et al. (1951), total lipids using the protocol of Dubinsky (1979) and total carbohydrates was calculated from the difference between organic matter and the sum of protein and lipid content (AOAC, 1995). The energetic content of the diets was estimated from three samples ( $0.5 \mathrm{~g}$ dry weight) of each strain using a microcalorimeter $\left(\mathrm{IKA}^{\circledR} \mathrm{C} 200\right.$, precision $\left.0.0001 \mathrm{~J} \mathrm{mg}^{-1}\right)$.

\section{Bivalve physiological measurements}

About 30 specimens of Argopecten nucleus (length 40 $\pm 0.1 \mathrm{~mm}$ and dry tissue weight $0.93 \pm 0.2 \mathrm{~g}$ ) and 30 specimens of Nodipecten nodosus (length $83+0.8 \mathrm{~mm}$ and dry tissue weight $5.55+1.6 \mathrm{~g}$ ) were obtained at the INVEMAR bivalve culture station at Neguanje Bay $\left(11^{\circ} 20^{\prime} \mathrm{N}, 74.05^{\prime} \mathrm{W}\right)$, in the Tayrona National Natural Park (PNNT), Colombia. The scallops were transported in humid condition to the Laboratorio de Moluscos y Microalgas where their shells were cleaned of encrustations and each individual was marked for identification. Acclimation to laboratory conditions was achieved by holding the scallops in an aerated $250 \mathrm{~L}$ seawater tank for one week at $25^{\circ} \mathrm{C}$ and salinity of 36 , while feeding them a microalgal suspension of laboratory-cultured Isochrysis galbana and $C$. calcitrans (1:1) at a rate of 3\% (dry biomass) of their dry body weight daily.

Two dietary treatments with monoalgal cultures of C. muelleri and C. calcitrans were tested. Each experimental diet was administered under constant conditions of temperature $\left(25^{\circ} \mathrm{C}\right)$, salinity (35), and microalgae concentration, a number of cells equivalent to $4.36 \pm 0.08 \mathrm{mg} \mathrm{L}^{-1}$ of dry weight $\left(17.3 \pm 0.4 \times 10^{6}\right.$ cells of $C$. calcitrans per $\mathrm{mL}$ and $13.1 \pm 0.7 \times 10^{6}$ cells of $C$. mиelleri per $\mathrm{mL}$ ). Seven test scallops were selected haphazardly for each feeding trial, and the trials were run for $15 \mathrm{~h}$, which included $12 \mathrm{~h}$ for feeding determinations and $2 \mathrm{~h}$ for the oxygen consumption and excretion measuring.

The experimental diets were administered using a flow-through system consisting of 16 chambers $(0.8 \mathrm{~L}$ for A. nucleus and $1.6 \mathrm{~L}$ for $N$. nodosus), designed following Riisgård (1977). A constant flow (150 \pm 10 $\mathrm{mL} \min ^{-1}$ ) of the experimental diet was directed by gravity from a mixing tank into each chamber; 14 chambers were used for individual bivalves (7 individuals of each species) and two chambers contained empty valves which served as controls. Valve opening by test specimens was continually observed and individuals which failed to open normally were eliminated from the experiment.

The experimental diets were prepared by mixing appropriate volumes of $1 \mu \mathrm{m}$ microfiltered seawater and microalgae which had been cultured in Guillard F/2 medium (Guillard, 1975) at $24^{\circ} \mathrm{C}$ and the conditions of light and salinity previously described, and used in the exponential phase.

The absorption rate (AR) was determined by the biodeposition method described by Iglesias et al. (1998), validated by Navarro \& Velasco (2003), using the 'flow-through chamber method' described by Riisgård (2001). Feces were quantitatively collected every hour using Pasteur pipettes. The mass and organic content of the feces produced by each test bivalve were estimated separately using the gravimetric method described above for the diet samples.

Oxygen consumption (OCR: $\mathrm{mL} \mathrm{O}_{2} \mathrm{~h}^{-1}$ ) and ammonium excretion (UR: $\mu \mathrm{g} \mathrm{NH}_{4}-\mathrm{N} \mathrm{h}^{-1}$ ) of both scallops were determined for each treatment on just fed animals by placing them in individual chambers $(0.8$ and $3 \mathrm{~L}$ for $A$. nucleus y $N$. nodosus, respectively) after rinsing the chambers with a $25 \% \mathrm{HCl}$ and filling with $<1 \mu \mathrm{m}$ filtered and aired seawater. Chambers were sealed and incubated for $2 \mathrm{~h}$ at the same temperature at which they were fed, alongside a control chamber devoid of specimens. Then two water samples were taken from each experimental chamber to determine oxygen consumption rates and rates of excretion. Oxygen consumption was never measured at ambient oxygen tension lower than $70 \%$ saturation. Oxygen concentration was estimated following the Winkler method as modified by Carritt \& Carpenter (Strickland $\&$ Parsons, 1972) and ammonia excretion was determined by the phenol-hypochlorite method (Widdows, 1985b).

Scope for growth (SFG) was calculated from the equation given by Widdows (1985a) after converting all the physiological rates to energy equivalents $\left(\mathrm{J} \mathrm{h}^{-1}\right)$ :

$$
\operatorname{SFG}\left(\mathrm{J} \mathrm{h}^{-1}\right)=\mathrm{A}-(\mathrm{R}+\mathrm{U})
$$

where $\mathrm{A}=$ energy absorbed $\left(\mathrm{J} \mathrm{h}^{-1}\right)=\mathrm{AR} \mathrm{mg} \mathrm{h}^{-1} \mathrm{x}$ energy content of each microalgae $\mathrm{J} \mathrm{mg}^{-1}$ (Table 2), $\mathrm{R}=$ oxygen consumption $\left(\mathrm{J} \mathrm{h}^{-1}\right)=\mathrm{OCR} \mathrm{mL} \mathrm{O}_{2} \times 20.08 \mathrm{~J}$ (Gnaiger, 1983), $\mathrm{U}=$ ammonium excretion $\left(\mathrm{J} \mathrm{h}^{-1}\right)=\mathrm{UR}$ $\mathrm{mg} \mathrm{NH}_{4}-\mathrm{N} \mathrm{h}^{-1} \mathrm{x} 24.8 \mathrm{~J}$ (Elliot \& Davison, 1975).

The physiological rates were converted to a standard individual of $1 \mathrm{~g}$ dry tissue weight and with a macroscopic gonadal stage of I (immature animals). For this, the soft tissues were dried at $70^{\circ} \mathrm{C}$ for $48 \mathrm{~h}$, and then individually weighed. Standardization employed the equation of Bayne et al. (1987):

$$
\mathrm{Yst}=(1 / \mathrm{We})^{\mathrm{b}} \mathrm{x} \mathrm{Ye}
$$


Table 2. Characterization of Chaetoceros muelleri and C. calcitrans and one-way ANOVA analyses results. Values are means \pm standard error. Different superscripts indicate significant differences between species.

\begin{tabular}{lccrc}
\hline & Chaetoceros calcitrans & Chaetoceros muelleri & $\mathrm{F}$ & $P$ \\
\hline Particulate organic matter $(\%)$ & $81.4 \pm 6.0^{\mathrm{a}}$ & $79.7 \pm 12.0^{\mathrm{a}}$ & 0.04 & 0.8427 \\
Size $(\mu \mathrm{m})$ & $5.0 \pm 2^{\mathrm{a}}$ & $5.5 \pm 1.5^{\mathrm{a}}$ & 0.99 & 0.3500 \\
Proteins $(\%)$ & $40.3 \pm 0.8^{\mathrm{b}}$ & $59.0 \pm 0.9^{\mathrm{a}}$ & 17.31 & 0.0141 \\
Lipids $(\%)$ & $23.0 \pm 1.4^{\mathrm{b}}$ & $31.0 \pm 1.3^{\mathrm{a}}$ & 23.06 & 0.0086 \\
Carbohydrates $(\%)$ & $37.0 \pm 1.1^{\mathrm{a}}$ & $10.0 \pm 0.9^{\mathrm{b}}$ & 32.80 & 0.0000 \\
Energetic content $\left(\mathrm{J} \mathrm{mg}^{-1}\right)$ & $22.9 \pm 0.4^{\mathrm{b}}$ & $25.1 \pm 0.3^{\mathrm{a}}$ & 58.08 & 0.0016 \\
\hline
\end{tabular}

where Yts $=$ standardized physiological rate, $\mathrm{Ye}=$ non standardized physiological rate, $\mathrm{We}=$ experimental animal weight $(\mathrm{g}), \mathrm{b}=$ dependence of the physiological rate to the size of the animals. $b$ values used were those determined previously for the studied scallops (Velasco, 2007).

\section{Statistical analysis}

Factorial repeated measures ANOVA was applied to determine the existence of significant differences of growth and biomass production of the microalgae strains among factors (species, media culture and environment culture). One-way ANOVA analyses were carried out to compare the bromatological contents of the microalgae strains as well as the scallop's physiological variables fed with both diatoms. Tests for normality (Kolmogorov-Smirnov) and homoscedasticity (C of Cochran) were carried out on all dependent variables. Excretion rates were In transformed, and absorption rates, oxygen consumption rate and scope for growth were transformed to square roots. The statistical analyses were carried out following Zar (1999) considerations and using Statgraphics-plus 5.0® and IBM SPSS 20 software, with a 0.05 alpha for the decisions.

\section{RESULTS}

\section{Microalgae characterization}

Cells of Chaetoceros muelleri (CHA-C-04) are similar to Chaetoceros calcitrans with rectangular shape in girdle view and elliptical shape in valve view. But local strain is slightly larger (between 4 and $9 \mu \mathrm{m}$ ), setae are longer (two times the pervalvar length) and straighter. C. muelleri presented significantly higher values of proteins, lipids and energy in comparison with $C$. calcitrans, but lower content of carbohydrates. The organic content, as well as the size of both microalgae were statistically similar.

\section{Microalgae culture experiment}

C. muelleri cultures with initial values of $0.6 \times 10^{3}$ cell $\mu \mathrm{L}^{-1}$ and $0.3 \mathrm{mg} \mathrm{mL}^{-1}$ obtained densities as high as
$8.7 \times 10^{3}$ cell $\mu \mathrm{L}^{-1}$, as well as maximum biomasses of 3.8 $\mathrm{mg} \mathrm{mL}{ }^{-1}$, in 6 days (Fig. 1). While C. calcitrans cultures with initial densities of $0.6 \times 10^{3}$ cell $\mu \mathrm{L}^{-1}$ and biomasses of $0.3 \mathrm{mg} \mathrm{mL}^{-1}$, after 7 days reached values of $8.5 \times 10^{3}$ cell $\mu \mathrm{L}^{-1}$ and $3.7 \mathrm{mg} \mathrm{mL}^{-1}$, respectively (Fig. 2). Specific growth rate $(\mathrm{K})$ was among 0.14 and $0.38 \mathrm{div}$ day $^{-1}$ in C. muelleri (Fig. 1), and between 0.07 and 0.32 div day ${ }^{-1}$ in C. calcitrans (Fig. 2). Excepting in $\mathrm{H}$ treatments, the density and biomass of $C$. muelleri and C. calcitrans had an exponential increase along the first six days of the culture (Figs. 1-2); after that, the values were stabilized; and finally, they decreased (between days 7 and 10 of the culture). None of the $\mathrm{H}$ treatments presented any significant increment in density nor in biomass $(P=1.00)$.

Repeated measures ANOVA analyses showed that the density and biomass of $C$. muelleri and $C$. calcitrans $(\mathrm{df}=1 ; \mathrm{F}=0.33 ; P=0.5765)$ were statistically similar. Additionally, they demonstrated a significant effect of the culture environment $(\mathrm{df}=1 ; \mathrm{F}=13.33 ; P=0.0011)$ and media ( $\mathrm{df}=2 ; \mathrm{F}=39.36 ; P=0.0000)$, and the interaction of both factors on the growth parameters. The density and biomass of $C$. muelleri maintained in $\mathrm{F} / 2$ were significantly higher than those of the other media $(P<0.001)$; while the values presented in the $\mathrm{H}$ media were significantly lower $(P<0.001)$. Both species growth was significantly higher under indoor conditions in comparison with outdoor treatments $(P<$ 0.003), except in the humus as well as in the $C$. muelleri with T15 treatments, where the culture environments did not affect growth parameters $(P>0.063)$.

\section{Bivalve physiological analysis}

The AR of Argopecten nucleus and Nodipecten nodosus were between 6.1 and $20.6 \mathrm{mg} \mathrm{h}^{-1} \mathrm{~g}^{-1}$ (Fig. 3a), OCR among 0.54 and $1.95 \mathrm{~mL} \mathrm{O}_{2} \mathrm{~h}^{-1} \mathrm{~g}^{-1}$ (Fig. 3b), and UR varied between 126.3 and $296.7 \mu \mathrm{g} \mathrm{NH}-\mathrm{H} \mathrm{h}^{-1} \mathrm{~g}^{-1}$ (Fig. 3c). SFG values were between 107.1 and $456.2 \mathrm{~J}$ $\mathrm{h}^{-1} \mathrm{~g}^{-1}$ (Fig. 3d). The type of microalgae strain does not have a significant effect over the $\mathrm{AR}(\mathrm{df}=1 ; \mathrm{F}=0.02$; $P>0.8962), \mathrm{OCR}(\mathrm{df}=1 ; \mathrm{F}=3.68 ; P=0.0686), \mathrm{UR}$ $(\mathrm{df}=1 ; \mathrm{F}=1.37 ; P=0.2543)$ and $\mathrm{SFG}(\mathrm{df}=1 ; \mathrm{F}=$ $0.01 ; P=0.9437)$. 

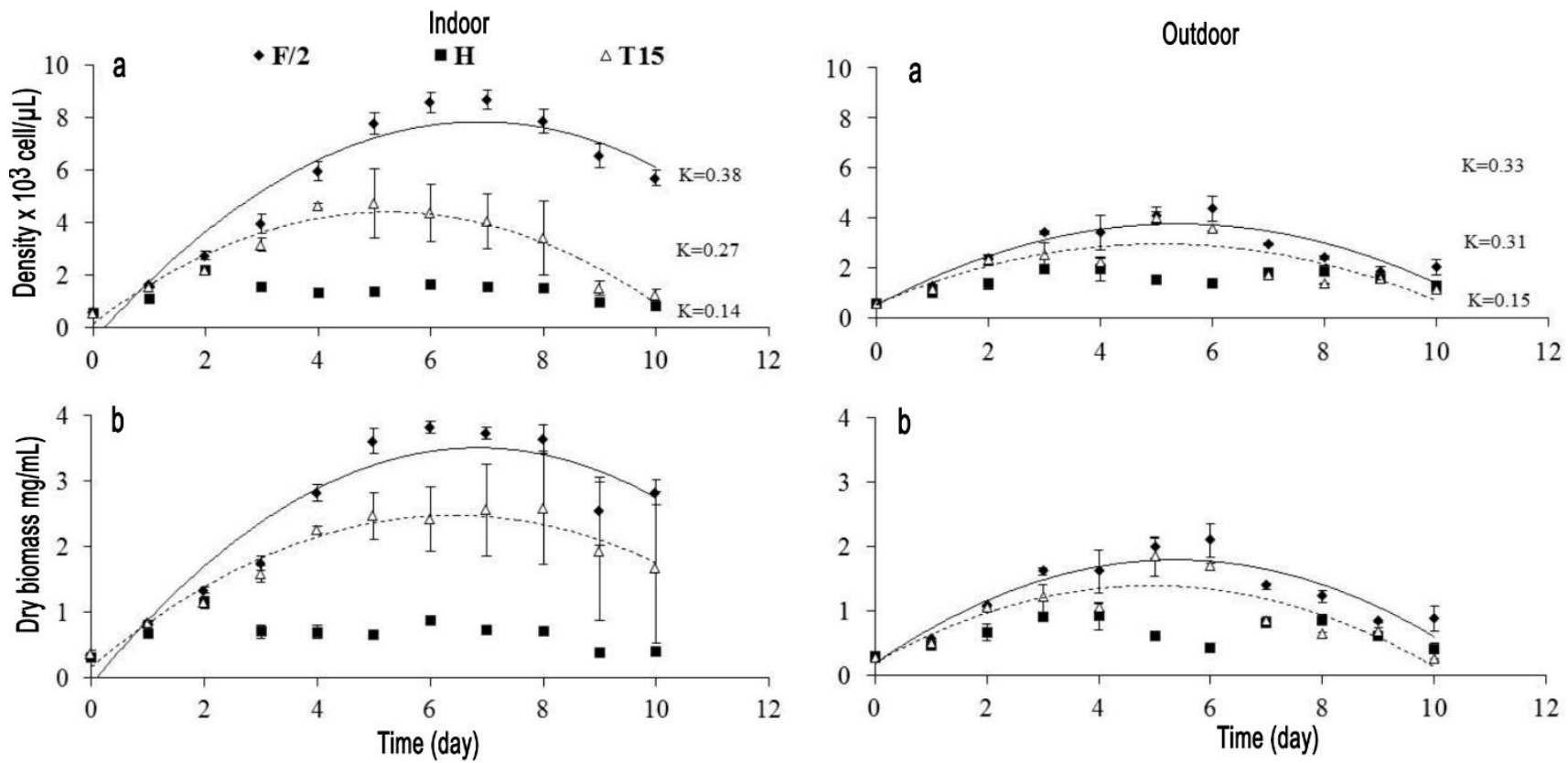

Figure 1. a) Growth in cell density and b) Biomass production of Chaetoceros muelleri cultured under different environment and culture media. F/2: Guillard f media, T15: triple15 (Nutrimon ${ }^{\circ}$, Monomeros, Colombia), H: humus extract (Nutrimon ${ }^{\circledR}$, Monomeros, Colombia) and K: growth rate values. Values are means \pm standard error.
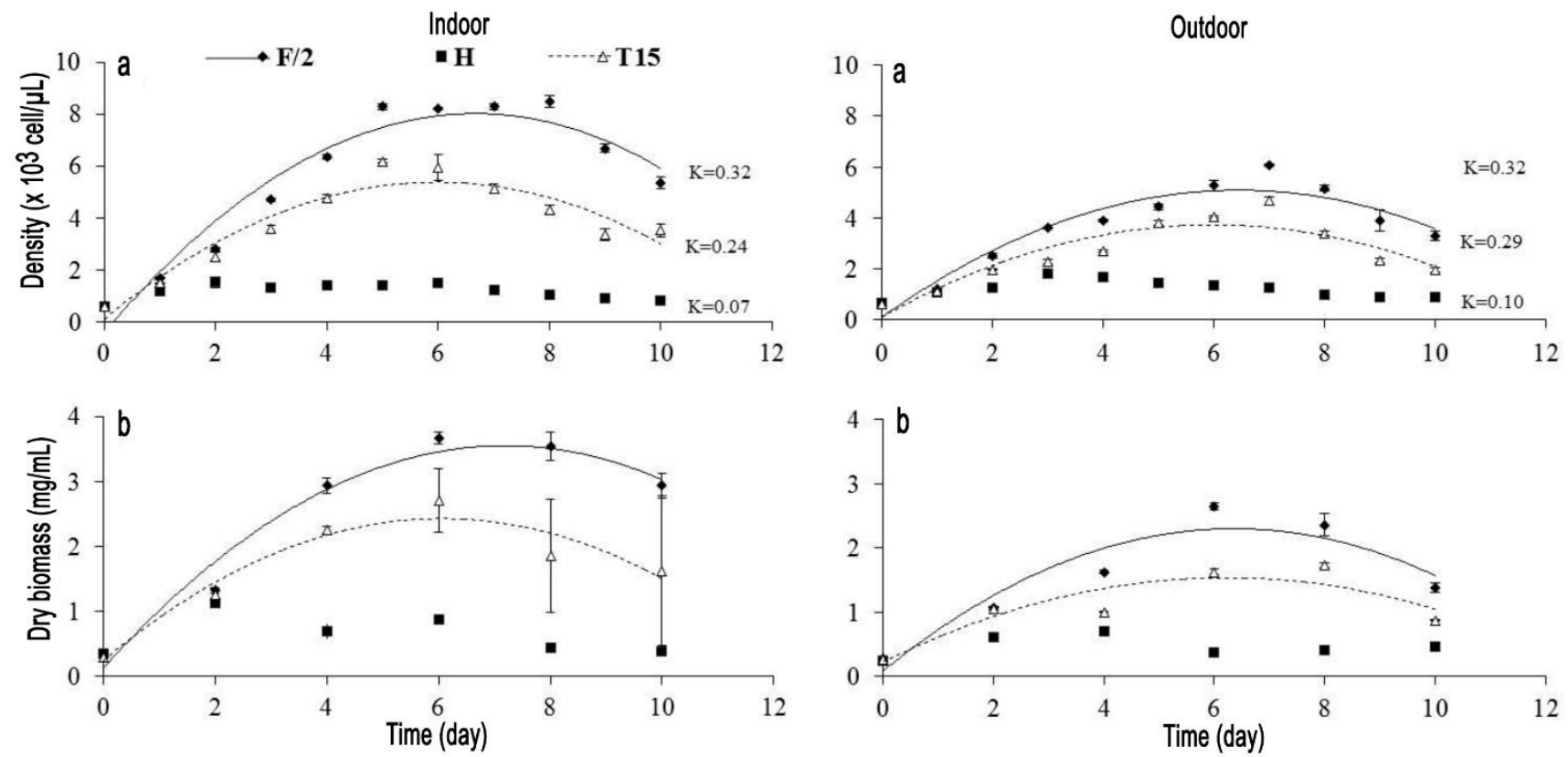

Figure 2. a) Growth in cell density and b) Biomass production of Chaetoceros calcitrans cultured under different environment and culture media. F/2: Guillard f media, T15: triple15 (Nutrimon ${ }^{\circledR}$, Monomeros, Colombia), H: humus extract (Nutrimon®, Monomeros, Colombia) and K: growth rate values. Values are means \pm standard error.

\section{DISCUSSION}

The higher growth of the local strain Chaetoceros muelleri cultured with the $\mathrm{F} / 2$ media in comparison with organic fertilizers (T15 and $\mathrm{H}$ ) agrees with the results obtained in some studies (Newmark et al., 1988;
Voltolina et al., 1998; González et al., 1999; Godinez et al., 2000; Prieto et al., 2005), but contradicts the positive results obtained with of organic fertilizers in other studies (Nieves et al., 1996; Valenzuela-Espinoza et al., 2002, 2005; Piña et al., 2007). The lack of micronutrients and/or the low values of $\mathrm{N}: \mathrm{P}$ in the orga- 

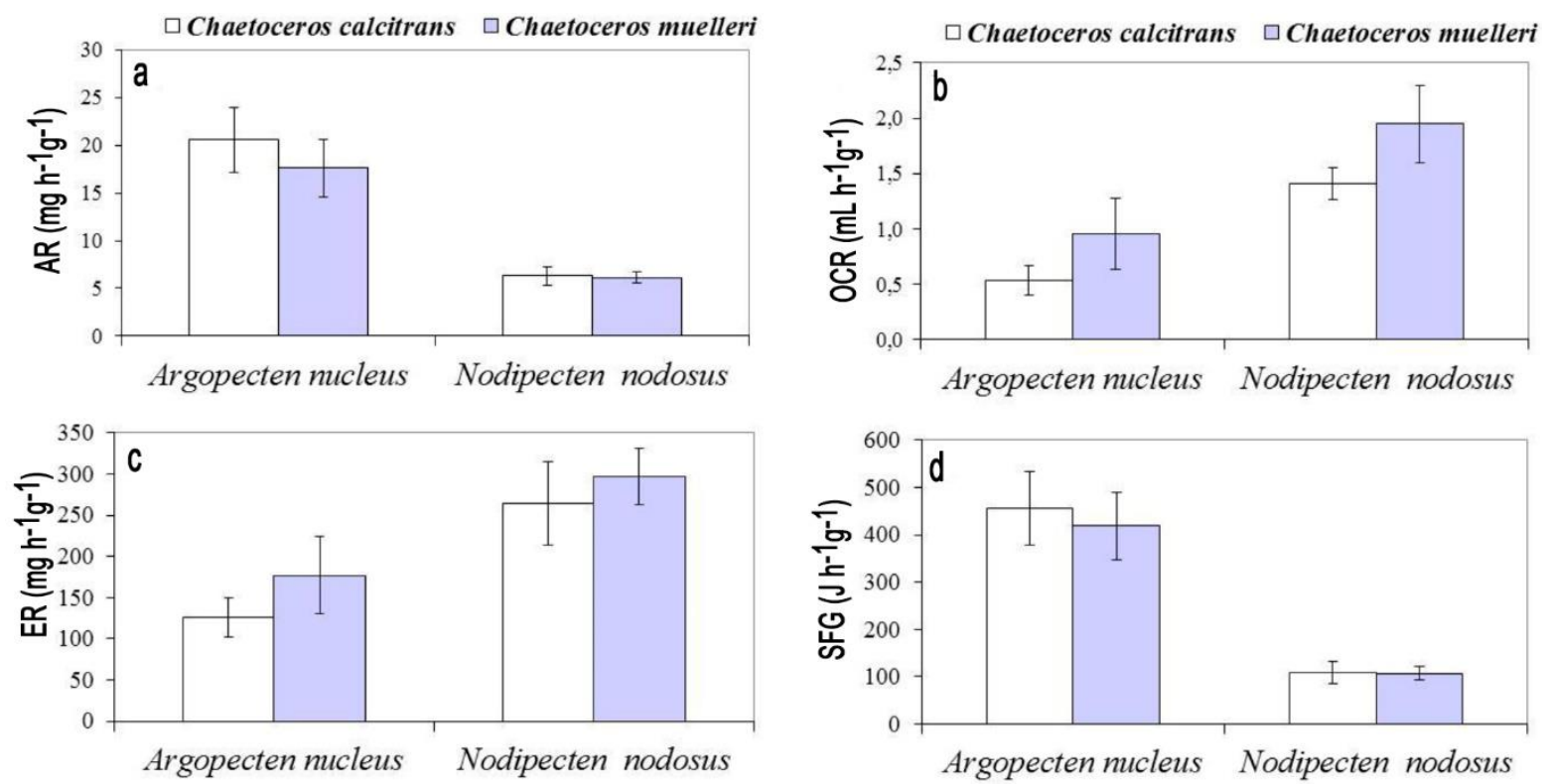

Figure 3. Physiological responses of Argopecten nucleus and Nodipecten nodosus feed with Chaetoceros calcitrans and Chaetoceros muelleri. a) Absorption rate, b) oxygen consumption rate, c) ammonium excretion rate, and d) scope for growth. Values are means \pm standard error.

nic fertilizers media (Table 1) could limit the photosynthesis and/or growth of both microalgae as have been reported previously in phytoplankton (Menzel \& Ryther, 1961) and benthic microalgae (Hillebrand \& Soomer, 1999). According to Takeda (1970) and Khoi et al. (2006), the optimal N:P value for Chaetoceros calcitrans growth is among 12 and 23. In this study, the F/2 treatments had a similar ratio at the beginning of the experiment, but the $\mathrm{N}: \mathrm{P}$ values of $\mathrm{H}$ and T15 treatments were lower (Table 1). These results suggest that the organic fertilizers media tested are inappropriate for the production of the diatoms strains studied.

The lower growth values densities and biomass production of $C$. muelleri under $\mathrm{F} / 2$ and outdoor conditions contradicts similar studies results (LópezElías et al., 2005; Banerjee et al. 2011) and the positive effect of high values of temperature and lighting on the tropical microalgae growth reported before (Rhee \& Gotham, 1981; Bermúdez et al., 2002; Renaud et al., 2002; Velasco et al., 2009b; Hemalatha et al., 2012). Considering that microalgal growth is affected by light and thermal acclimation (Karsten et al., 2006; Staehr \& Birkeland, 2006), it is possible that the two generations of previous microalgae exposition to the outdoor conditions were insufficient. So, the higher values of temperature and lighting under outdoor conditions could cause lower uptake of nutrients and/or photoinhibition as has been previously reported (Durbin, 1974; Vonshak \& Guy, 1992; Singh et al., 2015), in addition, microalgae cultures under outdoor conditions are more exposed to bacteria and protozoa contamination (Hu \& Gao, 2006; Sandnes et al., 2010), increasing the resource competence (Grossart, 1999) and the energetic costs for antimicrobial agents production (Fukami et al., 1997, Steinberg et al., 1997; Gross, 2003). On the other hand, the low and similar densities and biomass production of $C$. muelleri at indoor and outdoor conditions with organic fertilizers, suggests that under suboptimal media culture conditions, the culture environment is not important. Then, if the use of F/2 media culture and/or indoor facilities is not economically feasible, C. muelleri can be produced under outdoor conditions and using T15 media, obtaining around the half of the production showed in the optimal conditions.

The similar or higher cell and biomass production values of $C$. muelleri compared with $C$. calcitrans in this study and with those reported for the species and genera in other studies performed without the injection of $\mathrm{CO}_{2}$ (Table 3), indicates that the local strain can be produced using the same standard microalgae culture techniques.

Despite the higher protein, lipid and energy content of $C$. muelleri compared to $C$. calcitrans, the physiological rates of Argopecten nucleus and Nodipecten nodosus fed with these two diatoms were not different. Similar results have been reported for the physiological variables and/or growth of bivalves fed with microalgae strains from the same genus such as Isochrysis (Ewart \& Epifanio, 1981) and Chaetoceros (Velasco, 2007) or 
geographical origin (Brown et al., 1998). However, other studies have found that growth and/or survival variables of bivalves are higher when fed with some local algae strains such as Crassostrea gigas fed with Pavlova pinguis (Brown et al., 1998), Attheya septentrionalis, and Entomoneis cf punctulata (Knuckey et al., 2002) isolated in Australia, Placopecten magellanicus fed with Navicula pelliculosa, Chaetoceros septentrionalis and Prymnesium sp. isolated in Canada (Gouda et al., 2006). Those results are apparently related to their higher content of some polyunsaturated fatty acids, proteins and/or carbohydrates. Our results suggest that $C$. muelleri and $C$. calcitrans have similar nutritive values for $A$. nucleus and $N$. nodosus and that the protein, lipid and/or energetic content of these strains did not affect the scallops' physiological performance.

The higher somatic and gonadic growth values reported previously for A. nucleus and $N$. nodosus under sea suspended culture in comparison with those maintained in hatchery conditions (Rupp et al., 2005; Velasco \& Barros, 2007, 2009) do not appear be related with the presence of local microalgae such as $C$. muelleri in the diet. Other studies that have compared the nutritional value of local and traditional microalgae strains in bivalves have found different results. Brown et al. (1997) found that juveniles of $C$. gigas have a higher growth rate when fed with the local microalga $P$. pinguis in comparison with the non-indigenous strain, Isochrysis sp., similar results were obtained by Gouda et al. (2006) in P. magellanicus fed with local strains. On the other hand, Knuckey et al. (2002), obtained higher growth of $C$. gigas fed with the non-indigenous Thalassiosira pseudonana than when it was fed with the local algae Attheya septentrionalis and Entomoneis cf punctulata. Our results suggest that the nutritive value of the diatoms studied to be used as native scallops food does not be related to their geographical origin.

In conclusion, higher growth and biomass of the local strain $C$. muelleri were obtained using the $\mathrm{F} / 2$ media under indoor conditions as well as was verified in the traditional strain C. calcitrans. Both microalgae can be produced and used as feed for scallops with similar performance in microalgal growth, biomass production and scallops physiological condition. Then, C. muelleri could be produced and used as food for the Caribbean scallops, avoiding the microalgae importation and introduction risk of exotic species into the natural ecosystems, but do not offer any productive advantage.

\section{ACKNOWLEDGEMENTS}

The authors thanks L.A. Vidal, S. Sánchez, D. Vega, W. Barbosa, A. Barreto and E. Acosta for their help during the microalgae isolation and culture experiments. Finally, we thank B. Eizaga and S. Sarkis for their language and editorial corrections. This study was supported by University of Magdalena, projects FONCIENCIAS 012-2013 and 013-2011.

\section{REFERENCES}

Albentosa, M., A. Pérez-Camacho, U. Labarta \& M.J. Fernández-Reiriz. 1997. Evaluation of freeze-dried microalgal diets for the seed culture of Ruditapes decussatus using physiological and biochemical parameters. Aquaculture, 154: 305-321.

Andersen, R.A. \& M. Kawachi. 2005. Traditional microalgae isolation techniques. In: R.A. Andersen (ed.). Algal culturing techniques. Academic Press, New York, P: 83-99.

Angarita, R.C. \& G.E. Sánchez. 2003. Efecto de la temperatura, salinidad y medio de cultivo en el crecimiento de Cyclotella glomerata (Bacillariophyceae), proveniente de la Ciénaga grande de Santa Marta (CGSM), Caribe colombiano. X Congreso Latinoamericano de Ciencias del Mar, Santa Marta, pp: 1-6.

Association of Official Analytical Chemist (AOAC). 1995. Official methods of analysis. The Association of Official Analytical Chemist, Arlington, 1234 pp.

Banerjee, S., W. Hew, H. Khatoon, M. Shariff \& F. Yusoff. 2011. Growth and proximate composition of tropical marine Chaetoceros calcitrans and Nannochloropsis oculata cultured outdoors and under laboratory conditions. Afr. J. Biotechnol., 10(8): 13751383.

Bayne, B.L., A.J.S. Hawkins \& E. Navarro. 1987. Feeding and digestion by the mussel Mytilus edulis L. (Bivalvia: Mollusca) in mixtures of silt and algal cells at low concentrations. J. Exp. Mar. Biol. Ecol., 111: 122.

Bayne, B.L., M.N. Moore, J. Widdows, D.R. Living-Stone \& P. Salked. 1979. Measurement of the individuals to environmental stress and pollution: studies with bivalve mollusks. Philos. T. R. Soc. Biol. Lond. B, 286: 563-581.

Bermúdez, J.L., C. Lodeiros \& E. Morales. 2002. Producción de biomasa de la microalga marina Chroomonas sp. en función del $\mathrm{pH}$, intensidad luminosa y salinidad. Bol. Invemar, 31: 167-182.

Borowitzka, M.A. 1999. Commercial production of microalgae: ponds, tanks, tubes and fermenters. J. Biotechnol., 70: 313-321.

Brown, M.R., M. McCausland \& K. Kowalski. 1998. The nutritional value of four Australian microalgal strains 
fed to Pacific oyster Crassostrea gigas spat. Aquaculture, 165: 281-293.

Brown, M.R., S.W. Jeffrey, J.K. Volkman \& G.A. Dunstan. 1997. Nutritional properties of microalgae for mariculture. Aquaculture, 151: 315-331.

Cerón-Ortiz., A., B. Cordero, B. Arredondo-Vega \& D. Voltonina. 2009. Effect of algal diet and temperature on survival, growth and biochemical composition of spat of the lion's paw scallop Nodipecten subnodosus. Aquaculture, 298: 64-69.

Coutteau, P. \& P. Sorgeloos. 1992. The use of algal substitutes and the requirement for live algae in the hatchery and nursery rearing of bivalve mollusks: an international survey. J. Shellfish Res., 11: 467-476.

De Castro, S. \& G. Tavano. 2005. Growth and biochemical composition of the diatom Chaetoceros cf. wighamii Brightwell under different temperature, salinity and carbon dioxide levels. I. Protein, carbohydrates and lipids. Aquaculture, 246: 405-412.

De Pauw, N., J. Morales \& G. Persoone. 1984. Mass culture of microalgae in aquaculture systems: progress and constraints. Hydrobiology, 116: 121-134.

Durbin, H. 1974. Studies on the autecology of the marine diatom Thalassiosira nordenskioeldii Cleve. 1. The influence of day length, light, intensity and temperature on growth. J. Phycol., 10: 220-225.

Dubinsky, Z. 1979. Increase of lipid yields from some alga by acid extraction. Phytochemistry, 18: 51-52.

Elliot, S.M. \& W. Davison. 1975. Energy equivalents of oxygen consumption in animal energetics. Oecologia, 19: 195-201.

Ewart, J.W. \& C.E. Epifanio. 1981. A tropical flagellate food for larval and juvenile oysters, Crassostrea virginica Gmelin. Aquaculture, 22: 297-300.

Fabregas, J., L. Toribio, J. Abalde, A. Cabezas \& C. Herrero. 1987. Approach to biomass production of the marine microalgae Tetraselmis suecica (Kylin) Butch using common garden fertilizer and soil extract as cheap nutrient supply in batch cultures. Aquacult. Eng., 6: 141-150.

Fogg, G.E. 1965. Algal cultures and phytoplankton ecology. University of Wisconsin Press, Wisconsin, $1266 \mathrm{pp}$.

Fukami, K., T. Nishijima \& Y. Ishida. 1997. Stimulative and inhibitory effects on bacteria on the growth of microalgae. Hidrobiologia, 358: 185-191.

Gnaiger, E. 1983. Calculations of energetic and biochemical equivalents for respiratory oxygen consumption. In: E. Gnaiger \& H. Forstner (eds.). Polarographic oxygen sensor. Springer, Berlin, pp. 337-345.
Godínez, D., D. Voltolina, M. Nieves \& P. Piña. 2000. Organic fertilizers as nutrient sources for microalgae cultures. Riv. Ital. Acquacolt., 35: 75-80.

González, B., E. Buitrago \& K. Frontado. 1999. Evaluación de medios nutritivos para el crecimiento de tres microalgas marinas de uso común en acuicultura. Fundación la Salle Ciencias Naturales, 151: 75-84.

Gouda, R., E. Kenchington, B. Hatcher \& B. Vercaeme. 2006. Effects of locally-isolated micro-phytoplankton diets on growth and survival of sea scallop (Placopecten magellanicus) larvae. Aquaculture, 259: 169-180.

Grant J. \& P.J. Cranford. 1991. Carbon and nitrogen scope for growth as a function of diet in the sea scallop Placopecten magellanicus. J. Mar. Biol. Assoc., 71: 437-450.

Gross, E. 2003. Allelopathy of aquatic autotrophs. Crit. Rev. Plant. Sci., 22: 313-339.

Grossart, H.P. 1999. Interactions between marine bacteria and axenic diatoms (Cylindrotheca fusiformis, Nitzschia laevis, and Thalassiosira weissflogii) incubated under various conditions in the lab. Aquat. Microbiol. Ecol., 19: 1-11.

Guillard, R.R.L. 1973. Division rates. In: J.R. Stein (ed.). Handbook of phycological methods, culture methods and growth measurements. Cambridge University Press, Cambridge, pp. 289-312.

Guillard, R.R.L. 1975. Culture of phytoplankton for feeding marine invertebrates. In: W.L. Smith \& M.H. Chanley (eds.). Culture of marine invertebrate animals. Plenum Publishing Corporation, NewYork, pp. 29-60.

Harrison, P.J., R.E. Waters \& F.J.R. Taylor. 1980. A broad spectrum artificial sea water medium for coastal and open ocean phytoplankton. J. Phycol., 16: 28-35.

Hemalatha, A., P. Karthikeyan, K. Manimaran, P. Anantharaman \& P. Sampathkumar. 2012. Effect of temperature on the growth of marine diatom, Chaetoceros simplex (Ostenfeld, 1901) with different nitrate: silicate concentrations. Asian Pac. J. Trop. Biomed., 24: 1817-1821.

Hillebrand, H. \& U. Soomer. 1999. The nutrient stoichiometry of benthic microalgal growth: Redfield proportions are optimal. Limnol. Oceanogr., 44(2): 440-446.

Hoshaw, R.W. \& J.R. Rosowski. 1973. Methods for microscopic algae. In: J.R. Stein (ed.). Handbook of phycological methods: culture methods and growth measurements. Cambridge University Press, Cambridge, pp. 53-68.

Hu, H. \& K. Gao. 2006. Response of growth and fatty acid compositions of Nannochloropsis sp. to environmental 
factors under elevated $\mathrm{CO}_{2}$ concentration. Biotechnol. Lett., 28: 987-992.

Hustedt, F. 1930. Die Kieselalgen Deutschlands, Österreichs und der Schweiz. Dr. L. Rabenhorsts Kryptogamen-Flora von Deutschland, Österreich und der Schweiz, 7(1): 1-920.

Iglesias, J.I.P., M.B. Urrutia, E. Navarro \& L. Ibarrola. 1998. Measuring feeding and absorption in suspension-feeding bivalves: an appraisal of the biodeposition method. J. Exp. Mar. Biol. Ecol., 219: 71-86.

Karsten, U., R. Schumann. S. Rothe, I. Jung \& L. Medlin. 2006. Temperature and light requirements for growth of two diatom species (Bacillariophyceae) isolated from an Arctic macroalga. Polar Biol., 29(6): 476-486.

Khoi, C.M., V.T. Guong \& R. Merck. 2006. Growth of the diatom Chaetoceros calcitrans in sediment extracts from Artemia franciscana ponds at different concentrations of nitrogen and phosphorus. Aquaculture, 25: 250-269.

Knuckey, R., M. Brown, M. Barretta \& G. Hallegraeff. 2002. Isolation of new nanoplanktonic diatom strains and their evaluation as diets for juvenile Pacific oysters (Crassostrea gigas). Aquaculture, 211: 253-274.

Lananan F., A. Jusoh, N. Ali, S. Shiung \& A. Endut. 2013. Effect of Conway medium and $\mathrm{f} / 2$ Medium on the growth of six genera of South China Sea marine microalgae. Bioresource Technol., 141: 75-82.

Liang, Y., J. Beardall \& P. Heraud. 2006. Effects of nitrogen source and UV radiation on the growth, chlorophyll fluorescence and fatty acid composition of Phaeodactylum tricornutum and Chaetoceros muelleri (Bacillariophyceae). J. Photochem. Photobiol. B., 82: 161-172.

Liu, W., C.M. Pearce, A.O. Alabi \& H. Gurney-Smith. 2009. Effects of microalgal diets on the growth and survival of larvae and post-larvae of the basket cockle, Clinocardium nuttallii. Aquaculture, 293: 248-254.

López-Elías, J.A. \& D. Voltolina. 1993. Cultivos semicontinuos de cuatro especies de microalgas con un medio no convencional. Cienc. Mar., 19: 169-180.

López-Elías, J.A., D. Voltolina, F. Enríquez-Ocaña \& G. Gallegos-Simental. 2005. Indoor and outdoor mass production of the diatom Chaetoceros muelleri in a Mexican commercial hatchery. Aquacult. Eng., 33: 181-191.

López-Elías, J.A., D. Voltolina, C.O. Chavira-Ortega, B.B. Rodríguez, L.M. Sáenz-Gaxiola, B. CorderoEsquivel \& M. Nieves. 2003. Mass production of microalgae in six commercial shrimp hatcheries of the Mexican northwest. Aquacult. Eng., 29: 155-164.

Lowry, O.H., J. Rosebrough, A.L. Farr \& R.L. Randall. 1951. Protein measurement with the folin phenol reagent. J. Biol. Chem., 193: 265-275.
MacDonald, B.A. \& F. Bourne. 1987. Growth, reproductive output, and energy partitioning in weathervane scallop, Patinopecten caurinus from British Columbia. Can. J. Fish. Aquat. Sci., 44: 152160.

Marín, N., C. Lodeiros \& R. Verginelli. 1994. Cultivo de microalgas y el rotífero Brachionus pliacatilis en gran escala. Acta Cient. Venez., 45: 226-230.

Martínez-Fernández, E., H. Acosta-Salmo \& C. RangelDávalos. 2004. Ingestion and digestion of 10 species of microalgae by winged pearl oyster Pteria sterna (Gould, 1851) larvae. Aquaculture, 230: 417-423.

Menzel, D.W. \& J.H. Ryther. 1961. Nutrients limiting the production of phytoplankton in the Sargasso Sea with especial reference to iron. Deep-Sea Res., 7: 276-281.

Navarro, J.M., G.E. Leiva, G. Martinez \& C. Aguilera. 2000. Interactive effects of diets and temperature on the scope for growth of the scallop Argopecten purpuratus during reproductive conditioning. J. Exp. Mar. Ecol., 247: 67-83.

Navarro, J.M. \& L.A. Velasco. 2003. Comparison of two methods for measuring filtration rate in filter feeding bivalves. J. Mar. Biol. Assoc., 83: 553-558.

Newmark, F., M. Criales \& J. Blanco. 1988. Estandarización de seis cepas de microalgas con cuatro medios de crecimiento. Memorias III Reunión, Red Nacional de Acuicultura, Cali, pp. 149-161.

Nieves, M., D. Voltolina, J. López-Ruiz, M.A. Cisneros \& P. Piña. 2000. Cultivo de microalgas marinas con medios enriquecidos con productos de naturaleza zeolítica. Hidrobiológica, 10(1): 1-6.

Nieves, M., D. Voltolina, M.T. Sapién, H. Gerhardus, A.L. Robles \& M.A. Villa. 1996. Culturing microalgae with agricultural fertilizers. Riv. Ital. Acquacolt., 31: 81-84.

Pernet, F., R. Tremblay, E. Demersc \& M. Roussy. 2003. Variation of lipid class and fatty acid composition of Chaetoceros muelleri and Isochrysis sp. grown in a semicontinuous system. Aquaculture, 221: 393-406.

Pettersen, A., M. Giovanni, S. Jahangard, A. Brett, B. Ingram \& D.H. Craig. 2010. Effects of different dietary microalgae on survival, growth, settlement and fatty acid composition of blue mussel (Mytilus galloprovincialis) larvae. Aquaculture, 309: 115-124.

Piña, P., A. Medina, M. Nieves, S. Leal, J. López-Elías \& M. Guerrero. 2007. Cultivo de cuatro especies de microalgas con diferentes fertilizantes utilizados en acuicultura. Rev. Invest. Mar., 28(3): 225-236.

Ponis, E., R. Robert \& G. Parisia. 2003. Nutritional value of fresh and concentrated algal diets for larval and juvenile Pacific oysters (Crassostrea gigas) Aquaculture, 221: 491-505.

Prieto, M.J., M.J. Mogollón, A.L. Castro \& L.A. Sierra. 2005. Efecto del medio y condiciones de cultivo en la 
productividad de tres diatomeas marinas con potencial acuícola. Facultad de Medicina Veterinaria y Zootecnia, Universidad de Córdoba, Córdoba, pp. 544554.

Ragg, L.C., N. King, E. Watts \& J. Morrish. 2010. Optimising the delivery of the key dietary diatom Chaetoceros calcitrans to intensively cultured Greenshell ${ }^{\mathrm{TM}}$ mussel larvae, Perna canaliculus. Aquaculture, 306: 270-280.

Renaud, S.M., L.V. Thinh \& D. Parry. 1999. The gross chemical composition and fatty acid composition of 18 species of tropical Australian microalgae for possible use in mariculture. Aquaculture, 170: 147-159.

Renaud, S.M., L.V. Thinh, G. Lambrinidis \& D.L. Parry. 2002. Effect of temperature on growth, chemical composition and fatty acid composition of tropical Australian microalgae grown in batch cultures. Aquaculture, 211: 195-214.

Rhee, G.Y. \& I.J. Gotham. 1981. The effect of environmental factors on phytoplankton growth: temperature and the interactions of temperature with nutrient limitation. Limnol. Oceanogr., 26(4): 635648.

Riisgård, H.U. 1977. On measurements of the filtration rates in suspensions-feeding bivalves in a flow system. Ophelia, 16: 167-173.

Riisgård, H.U. 2001. On measurement of filtration rates in bivalves-the stony road to reliable data: review and interpretation. Mar. Ecol. Prog. Ser., 211: 275-291.

Riisgård, H.U. \& A. Randløv. 1981. Energy budgets, growth and filtration rates in Mytilus edulis at different algal concentration. Mar. Biol., 61: 227-234.

Rines, J.E.B. \& P.E., Hargraves, 1988. The Chaetoceros Ehrenberg (Bacillariophyceae) flora of Narragansett Bay, Rhode Island, U.S.A. Bibl. Phycol., 79: 1-196.

Rupp, G., J. Parsons, R. Thompson \& M. Bem. 2005. Influence of environmental factors, season and size at deployment on growth and retrieval of postlarval lion's paw scallop Nodipecten nodosus (Linnaeus, 1758) from a subtropical environment. Aquaculture, 243: 195-216.

Sánchez-Saavedra, M.P. \& D. Voltolina. 1994. The chemical composition of Chaetoceros sp. (Bacillariophyceae) under different light conditions. Comp. Biochem. Physiol. B., 107: 39-44.

Sánchez-Saavedra, M.P. \& D. Voltonina. 2006. The growth rate, biomass production and composition of Chaetoceros sp. grown with different light sources. Aquacult. Eng., 35: 161-165.

Sandnes, J.M., J.M.T. Källqvist, D. Wenner \& H.R. Gislerød. 2010. Combined influence of light and temperature on growth rates of Nannochloropsis oceanica: linking cellular responses to large-scale biomass production. J. Appl. Phycol., 17(6): 515-525.
Singh, S.P. \& P. Singh. 2015. Effect of temperature and light on the growth of algae species: a review. renewable and sustainable energy reviews, 50: 431444.

Staehr, P.A. \& M.J. Birkeland. 2006. Temperature acclimation of growth, photosynthesis and respiration in two mesophilic phytoplankton species. Phycologia, 45(6): 648-656.

Steinberg, P., R. Schneider \& S. Kjelleberg. 1997. Chemical defenses of seaweeds against microbial colonization. Biodegradation, 8: 211-220.

Strickland, J.D.H. \& T.R. Parsons. 1972. A practical handbook of seawater analysis. J. Fish. Res. Bd. Can., 167: $310 \mathrm{pp}$.

Takeda, S. 1970. Influence of iron availability on nutrient consumption ratio of diatoms in oceanic waters. Nature, 393: 774-777.

Valenzuela-Espinoza, E., R. Millán-Núñez \& F. NúñezCebrero. 2002. Protein, carbohydrate, lipid and chlorophyll-a content in Isochrysis aff. galbana (clone T-Iso) cultured with a low cost alternative to the $f / 2$ medium. Aquacult. Eng., 25: 207-216.

Valenzuela-Espinoza, E., F. Lafarga-De la Cruz, R. Millan-Nuñez \& F. Nuñez-Cerebro. 2005. Crecimiento, consumo de nutrientes y composición proximal de Rhodomonas sp. cultivada con medio f/2 y fertilizantes agrícolas. Cienc. Mar., 31: 79-89.

Velasco, L.A. 2006. Effect of microalgal concentration and water temperature on the physiology of the Caribbean scallops Argopecten nucleus and Nodipecten nodosus. J. Shellfish Res., 25(3): 823-831.

Velasco, L.A. 2007. Energetic physiology of the Caribbean scallops Argopecten nucleus and Nodipecten nodosus fed with different microalgal diets. Aquaculture, 270: 299-212.

Velasco, L.A. 2008. Acondicionamiento reproductivo de los pectínidos de interés comercial de Colombia. En: L.A. Velasco (ed.). Biología y cultivo de los pectínidos de interés comercial de Colombia. Fondo de Publicaciones de la Universidad del Magdalena, Santa Marta, pp. 65-86.

Velasco, L.A. \& J. Barros. 2007. Potential for hatchery broodstock conditioning of the Caribbean scallops Argopecten nucleus and Nodipecten nodosus. Aquaculture, 272: 767-773.

Velasco, L.A. \& J. Barros. 2009. Survival and growth of hatchery-produced postlarvae and spat of the Caribbean scallops Argopecten nucleus and Nodipecten nodosus. Aquacult. Res., 40: 362-375.

Velasco, L.A., J. Barros \& A. Guerrero. 2009a. Effect of the density on the growth and survival of the Caribbean 
scallops Argopecten nucleus and Nodipecten nodosus in suspended culture. Aquacult. Res., 40: 687-695.

Velasco, L.A., J. Barros, G.H. Ospina-Salazar \& C. Trujillo. 2009b. Efecto de la intensidad lumínica, temperatura, y salinidad sobre el crecimiento de la microalga Isochrysis galbana (clon T-ISO). Intropica, 4: 96-99.

Volkman, J.K., S.W. Jeffrey, P.D. Nichols, G.I. Rogers \& C.D. Garland. 1989. Fatty acid and lipid composition of 10 species of microalgae used in mariculture. J. Exp. Mar. Biol. Ecol., 128: 219-240.

Voltolina, D., M. Nieves, G. Navarro, T. Oliva \& D. Peraza. 1988. The importance of acclimation for the evaluation of alternative media for microalgae growth. Aquacult. Eng., 19: 7-15.

Vonshak, A. \& R. Guy, 1992. Photoadaptation, photoinhibition and productivity in the blue-green alga, Spirulina platensis grown outdoors. Plant Cell Environm., 15: 613-616.

Received: 27 January 2015; Accepted: 26 April 2016
Walne, P.R. 1966. Experiments in the large scale culture of the larvae of Ostrea edulis L. Fish. In. Min. Fish. Food, 24(4): 8-14.

Widdows, J. 1985a. Physiological ecology mussel larvae. Aquaculture, 94: 147-163.

Widdows, J. 1985b. Physiological procedures. In: B.L. Bayne (ed.). The effects of stress and pollution on marine animals. Praeger, New York, pp. 161-178.

Zar, J. 1999. Biostatistical analysis. Prentince Hall, New Yersey, $570 \mathrm{pp}$.

Zhukova, N. \& N. Aizdaicher. 1995. Fatty acid composition of 15 species of marine microalgae. Phytochemistry, 39: 351-356. 